\title{
Bullous Sweet's Syndrome: Report of an Atypical Case Presenting with Ring-Like, Figurate Lesions
}

\author{
Büllöz Sweet Sendromu: Halka Benzeri, Figüre Lezyonlarla Ortaya Çıkan Atipik Bir Olgu Sunumu
}

Andaç Salman¹, Aida Berenjian¹, Ali Eser², Fatma Dilek Kaymakçı ${ }^{3}$ Leyla Cinel³, Işık Kaygusuz Atagündüz², Deniz Yücelten¹, Tülin Ergun¹

1 Marmara University Faculty of Medicine, Department of Dermatology, Istanbul, Turkey

2 Marmara University Faculty of Medicine, Department of Hematology, Istanbul, Turkey

${ }^{3}$ Marmara University Faculty of Medicine, Department of Pathology, Istanbul, Turkey

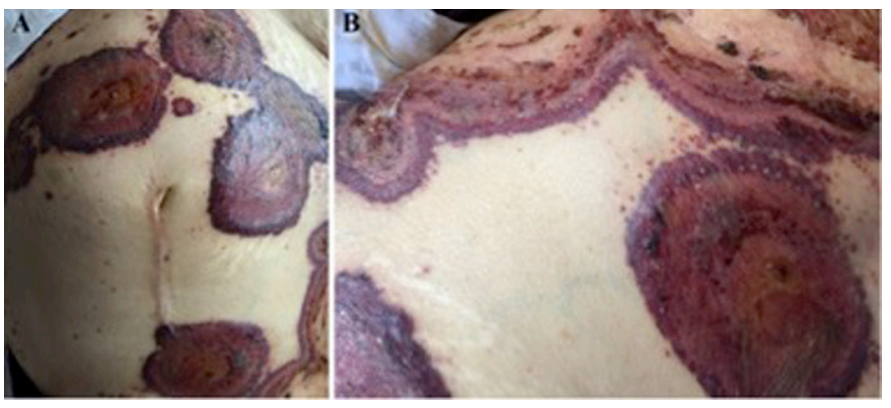

Figure 1. Widespread, erythematous, ring-like plaques with peripheral blisters on the trunk ( $A$ and $B)$.

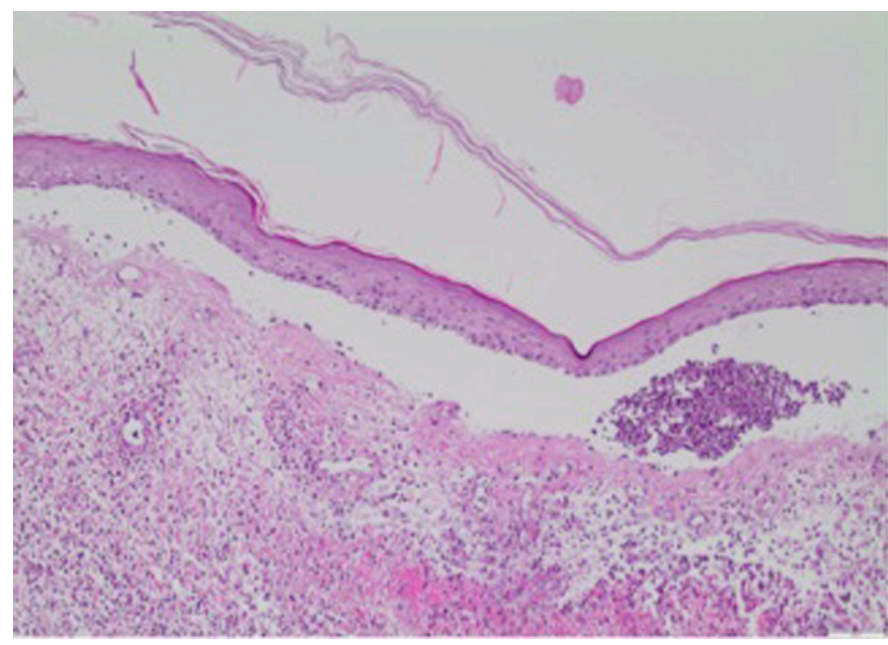

Figure 2. Dermal infiltrate rich in neutrophils with subepidermal blister formation $\left(\mathrm{H} \& \mathrm{E}, 20^{\mathrm{x}}\right)$.
A 68-year-old woman presented with a 2-month history of erythematous, blistering lesions refractory to systemic antibiotic treatment. Her medical history was insignificant except for longstanding diabetes mellitus, hepatitis $C$ infection, and recently diagnosed myelodysplastic syndrome, refractory anemia with excess blasts-1 (MDS-RAEB-1). She denied any recent intake of drugs prior to the onset of skin lesions. Dermatological examination revealed widespread, erythematous, concentric, circinate large plaques with peripheral bullae formation over the trunk and extremities (Figures 1A and 1B). Laboratory tests disclosed leukocytosis $\left(32 \times 10^{9} / \mathrm{L}\right)$ with neutrophilia $\left(7.2 \times 10^{9} / \mathrm{L}\right)$, anemia (hemoglobin: $76 \mathrm{~g} / \mathrm{L})$, thrombocytopenia (16x109/L), elevated levels of C-reactive protein (1133.36 nmol/L) and erythrocyte sedimentation rate $(111 \mathrm{~mm} / \mathrm{h})$, normal levels of aspartate aminotransferase (0.17 $\mu \mathrm{kat} / \mathrm{L})$ and alanine aminotransferase $(0.22 \mu \mathrm{kat} / \mathrm{L})$, and hepatitis $C$ virus-ribonucleic acid (HCV-RNA) negativity. A punch biopsy was obtained with a differential diagnosis of bullous Sweet's syndrome (SS) and erythema gyratum repens. Histopathology showed diffuse, dermal inflammatory infiltrate rich in neutrophils with subepidermal blister formation (Figure 2). Clinical and laboratory findings confirmed the diagnosis of bullous SS associated with MDS-RAEB-1. In addition to topical corticosteroids and oral colchicine, treatment with azacitidine led to rapid resolution of

๑Copyright 2017 by Turkish Society of Hematology

Turkish Journal of Hematology, Published by Galenos Publishing House

口, Address for Correspondence/Yazışma Adresi: Andaç SALMAN M.D.,

Marmara University Faculty of Medicine, Department of Dermatology, İstanbul, Turkey

Received/Geliş tarihi: May 16, 2015

Phone : +90 21665706 06-3533

E-mail : asalmanitf@gmail.com, andac.salman@marmara.edu.tr 
the lesions. There was no recurrence of SS until the patient's death before the second azacitidine cycle.

SS is characterized by erythematous, tender plaques and papules involving the head, neck, and upper extremities $[1,2]$. It may be associated with infections, hematologic malignancies, inflammatory bowel disease, and drugs [2]. SS may also be associated with chronic active hepatitis; however, normal liver function tests, HCV-RNA negativity, and the temporal relationship between skin lesions and hematological findings in our case make this unlikely. Although pseudovesicular appearance due to severe edema can be seen in SS, bullae formation with figurate and ring-like lesions is rare $[3,4,5]$. Figurate lesions without bullae in SS were previously reported in a patient with no associated disease [3]. In conclusion, the diagnosis of SS should be kept in mind in patients with erythema gyratum repens-like or concentric blistering lesions.

Keywords: Bullous, Figurate erythema, Myelodysplastic syndrome, Sweet's syndrome
Anahtar Sözcükler: Büllöz, Figüre eritem, Miyelodisplastik sendrom, Sweet sendromu

Conflict of Interest: The authors of this paper have no conflicts of interest, including specific financial interests, relationships, and/or affiliations relevant to the subject matter or materials included.

\section{References}

1. Anzalone CL, Cohen PR. Acute febrile neutrophilic dermatosis (Sweet's syndrome). Curr Opin Hematol 2013;20:26-35.

2. Paydas S. Sweet's syndrome: a revisit for hematologists and oncologists. Crit Rev Oncol Hematol 2013;86:85-95.

3. Behm B, SchremI S, Landthaler M, Babilas P. Sweet's syndrome masquerading as figurate erythema. Int J Dermatol 2012;51:1101-1103.

4. Neoh CY, Tan AWH, Ng SK. Sweet's syndrome: a spectrum of unusual clinical presentations and associations. Br J Dermatol 2007;156:480-485.

5. Voelter-Mahlknecht S, Bauer J, Metzler G, Fierlbeck G, Rassner G. Bullous variant of Sweet's syndrome. Int J Dermatol 2005;44:946-947. 